\title{
5. The fame of a Masterwork
}

\author{
F. W. N. HUGENHOLTZ
}

The year 1969 saw the fiftieth anniversary of the first Dutch edition of Herfsttij der Middeleeuwen. To mark this occasion the publisher invited me to write an essay on the history of Herfsttij and its translations, an essay which served as an introduc-

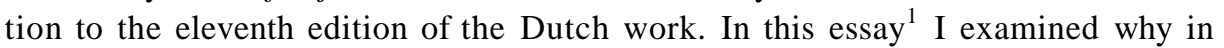
1919 Herfsttij had met with such a cool reception from the leading Dutch historians of that period. The organizers of the present conference have asked me to extend the field of my researches and to investigate how Herfsttij, once it was translated into various languages, acquired its great international reputation. ${ }^{2}$ But it is no easy task to measure a reputation. It is true that popularity may to some extent be estimated by adding up the number of editions, impressions and translations. Such figures however reveal nothing about the kind of impact the book made on its readers nor why they bought it. I decided therefore not to consider that question but to concentrate on other aspects of the problem.

Looking at the list of impressions and translations one is immediately struck by three interesting facts. Firstly, the book was reprinted much more often in Germany or Switzerland than in any other country outside the Netherlands. Secondly, the French translation was published eight years later than the English and German translations. Thirdly, from the midthirties onward there was, both in the Netherlands and in Germany and Switzerland, a sharply increased demand for Herfsttij. The first three Dutch editions appeared in 1919, 1921 and 1928; the fourth did not appear until 1935. In Germany there were editions in 1924,1928 and 1931, then two in quick succession in 1938 and 1939. It looks as though in both countries a slackening of interest occurred, followed by a sort of revival - a revival which, in my opinion, must be due to outside factors. It is not difficult to guess that the publication of Huizinga's In the Shadow of Tomorrow (1935 in Dutch and German, 1936 in English) has a great deal to do with this development. This has obliged me to confine my investigations to the period from 1919 to 1935 , leaving aside the trans-

1. A French translation of this essay: F. W. N. Hugenholtz, 'Le Déclin du Moyen Age (19191969)', Acta Historiae Neerlandica, V (1971) 40-51.

2. I am very grateful for the help my assistant Mr Peter Raedts gave in the course of the investigation. 
lations made after In the Shadow of Tomorrow achieved, in many languages, its huge success during the late 1930s.

Apart from these few facts there is little more information to be gained from studying Herfsttij's printing history. Unfortunately it is even impossible to establish exactly the total number of printed copies, as some publishers refuse to provide details. However this should not distress us too much. We may be satisfied with the obvious statement that Herfsttij became a very widely-read work, so successful all over the world that its author felt embarrassed by it. ${ }^{3}$ My theme, though, will be a different one. All I want to examine in this essay is the way Herfsttij was received by professional historians during the early stages of its career as a book. I have said before that this reception was cool and my purpose is to explain why this was so. $^{4}$

Dr. Kurt Köster, one of the firstbiographers of Huizinga, and the first to publish a list of his works, ${ }^{5}$ has made a few remarks which may serve as a point of departure. In one passage Köster mentions Herfsttij as 'the book that was to make Huizinga's name world-famous'. ${ }^{6}$ This is a statement, also made by others, which has never been proved and it may be less true than most people think. It should be noted that Köster formulated his statement very cautiously, not saying that Herfsttij made Huizinga world-famous, but that it was to make him so, which suggests that some time elapsed before his fame was established.

Later on in his biography Köster writes that Herfsttij is an 'unusual book', and he is not surprised that such a work was not immediately understood and appreciated. He also notices that it was received rather coolly in the Netherlands. But then he puts forward a hypothesis which he does not try to prove, stating that it was due only to the success of the book outside the Netherlands, especially in Germany, that the reservations of the Dutch historians were at first slowly but later completely overcome. ${ }^{7}$

Why does Dr. Köster call Herfsttij an 'unusual' book? He is by no means the only author to do so. In his small book about Huizinga, Professor Kaegi, for example, writes that one of the most important qualities of Herfsttij is that it was created through 'an unusual historical sensorium', 'sensorium' probably meaning 'senseorgan' as well as 'perceptive feeling'. The book, according to Kaegi, surprised most

3. Letter from Huizinga to his publisher, Jan. 5th 1920.

4. During the discussion on this paper Professor Gombrich remarked that this 'lack of enthusiasm' might be due to the fact that most of the reviewers belonged to the older generation. I am grateful for this suggestion. Up till now however I have been unable to look into this matter further.

5. Kurt Köster, Johan Huizinga 1872-1945 (Oberursel, 1947). I have gratefully used the extensive list of reviews which Dr. Köster prints in this book.

6. Ibidem, 28.

7. Ibidem, 31 . 
readers, since they were accustomed to seeing the late Middle Ages as the precursor of Reformation and Renaissance and had studied the period from the angle of urban economie history and the history of international power politics, which made it more comprehensible and attractive to the modern mind. People were struck by the fact that in Herfsttij, as Kaegi put it, 'the rambling colourful tales of the chroniclers had not been consigned to the historical lumber-room (die historische Rumpelkammer), but had been listened to, understood and illuminated by historical perception'.

Both Kaegi and Köster wrote in 1947. Did Herfsttij really appear 'unusual' at the time of its publication? With this question in mind, my assistant and I read a large number of reviews. Many of them, unfortunately, are little more than short notices without value for our purpose. Moreover, in reading all these reviews of the Dutch version as well as of the translations, I became very much aware of the difficulty of drawing general conclusions from reactions which in many respects turned out to be highly idiosyncratic. Each country where Herfsttij was reviewed had its own climate of opinion and its own fashion in historical scholarship. And, of course, much depended simply on the moment when the translation happened to be published. Several non-Dutch reviewers, for example, discussed the same short paragraph in Herfsttij's first chapter. (III, 12-3) Two German reviewers thought it was superfluous, as in their view Huizinga was spelling out the obvious, while a Frenchman described it as good, important and useful. Only one of the reviewers suspected that he was directing attention to something of great importance, and none of them could have known that this very passage must play an important role in any general survey of the reactions to the book.

This passage occurs in the chapter, headed 'The Violent Tenor of Life', in which Huizinga writes about the passions and childlike fantasy which had such an impact on late mediaeval life. He states that modern scholars may be making a serious mistake in choosing to use official charters and not chronicles because the latter contain a great number of errors of fact. But whereas charters tell us very little about the emotions and passions which swayed mediaeval people, the chronicles describe these fully and vividly and, in spite of their superficiality and unreliability, they reflect essential aspects of mediaeval reality.

I do not think that the lines I have just summarized were intended by Huizinga as a challenging statement of principle; in that case he would have given the passage the only in Herfsttij about a methodological issue - more prominence and might well have expanded it. Yet his point was taken up by the reviewers. Hans Kaiser, who in 1924 reviewed the first Dutch edition in the Historische Zeitschrift, wrote that Huizinga's reproach was unnecessary: 'Is there any one who can seriously

8. Werner Kaegi, Das historische Werk Johan Huizingas (Leyden, 1947) 21. 


\section{F. W. N. HUGENHOLTZ}

maintain that mediaeval history can be written exclusively on the basis of official documents to the neglect of narrative sources?' ${ }^{9}$ After reading the second German edition, Mare Bloch, on the other hand, agreed wholeheartedly with Huizinga's plea on behalf of narrative sources and stated this explicitly in 1928 in Strasbourg. ${ }^{10}$ In 1926 another German reviewer, Franz Arens, made an effort to understand Huizinga's position but ultimately rejected it. He wrote:

One continually perceives an idealistic spirit trying to make its way through the contemporary climate of ideas, which appears to be ruled exclusively by political and economie considerations and values. (And he continues:) Perhaps we should presume a typically Dutch situation as the background here; in our country this kind of zeal would seem to be tilting at windmills. ${ }^{\text {" }}$

In 1968, finally, Professor Rosalie Colie said in a somewhat generalizing way that Huizinga used in his book sources 'normally overlooked by the working historian'. ${ }^{12}$

Thus, more than twenty years before Dr. Köster, a previous German author surmised that there existed in the field of Dutch mediaeval studies a situation which might explain Huizinga's attitude. What then was this situation - and is it true that Huizinga's assessment of the value of narrative sources did provoke a strong reaction on the part of his Dutch colleagues? The second question, as it stands, cannot be answered. In one professional journal specially concerned with Dutch history, ${ }^{13}$ not one word about Herfsttij was to be found. In the other professional journal, the Tijdschrift voor Geschiedenis, the mediaevalist Tenhaeff took one and a half pages to say that it was a pleasant book but that on two points serious criticism was called for: firstly Huizinga overemphasized the French element in Burgundian culture and secondly he neglected politics although this also is an expression of culture. ${ }^{14}$ Tenhaeff discussed neither Huizinga's method nor his sources and on the basis of his review it would have been impossible to predict that the book could ever come to be regarded as a classic masterpiece. For the time being no other review appeared in the Netherlands: the historical periodicals said no more about it for years. Köster, therefore, was right. As a matter of fact, some Dutch writers had commented long before him upon the singularly cool reaction of Dutch historical scholarship. In 1930 P. N. van Eyck and Menno ter Braak remarked that Huizinga's colleagues received Herfsttij with suspicion and embarrassing reserve,

9. Hans Kaiser, Historische Zeitschrift, CXXIX (1924) 302.

10. Marc Bloch, Bulletin de la Faculté des Lettres de Strasbourg, VII (1928) 33-35.

11. Franz Arens, Archiv für Politik und Geschichte, VI (1926) 521.

12. Ros. Colie, International Encyclopedia of the Social Sciences, VI (1968) 533.

13. Bijdragen voor Vaderlandsche Geschiedenis en Oudheidkunde.

14. N. B. Tenhaeff, Tijdschrift voor Geschiedenis, XXXV (1920) 408-409. 
whereas - Van Eyck went on - Dutch literary journals had acclaimed the appearance of Herfsttij with warm applause. ${ }^{15}$ Why the reserve of the historians?

In 1919 Dutch mediaeval studies were still in their infancy, even though archivists and professors such as Fruin, Blok and later on Gosses had made individual contributions in the field. It was only shortly after 1900 that in Utrecht the first Chair of Mediaeval History was established; it was held by the German Otto Oppermann, who had been trained in the rigorous German school. After that, the Catholic University of Nijmegen also appointed a professor of mediaeval history but before 1940 no other university in the Netherlands followed suit. The technique of scientific diplomatics had not yet been used for systematically examining Dutch mediaeval documents, still largely unpublished. Diplomatic studies constituted the major interest of the Utrecht school and it was necessary that it should be so. In comparison with other countries, Dutch mediaeval scholarship was very much behindhand, particularly in institutional, political and economie history. A great deal of work was now done, pioneering work with the one-sidedness that often accompanies it, but important results were obtained. It soon became evident, however, that such an almost fanatic application of the rules of diplomatics could lead to a hypercritical attitude. Thus a number of charters were adjudged to be false, which, it turned out later, were in fact perfectly authentic. Furthermore, this preoccupation with diplomatic material and, through it, with politico-institutional history led to an extremely one-sided evaluation of the narrative sources. These were seen as for the most part highly unreliable, and were therefore to all intents and purposes rejected as historical sources. This was an attitude which mediaevalists elsewhere had adopted too, for instance in Germany in the middle of the nineteenth century, but there this stage in the development of mediaeval studies had long since been left behind. The very late development of Dutch mediaeval scholarschip was due to the fact that the nation's most glorious history lay not in the Middle Ages but in the sixteenth and seventeenth centuries. The less spectacular history of the Middle Ages, which were, moreover, Catholic in their spiritual climate, held little attraction for Dutch nineteenth-century historians.

This was the situation in which Huizinga lived and worked. Through various circumstances his first publications in the historical field (1905-6) were related to a subject which in the perspective of his previous as well as of his later preoccupations may be considered rather eccentric and unexpected: the early history and institutions of the town of Haarlem. On the suggestion of the archivist S. Muller of Utrecht, he also edited, in 1911, the legal source material pertaining to this town. ${ }^{16}$ To pass from ancient Indian literature to the history of mediaeval Haarlem was a

15. M. ter Braak, De Stem, X (1930) 822-839; P. N. van Eyck, Leiding, I (1930) 203-222.

16. J. Huizinga, Rechtsbronnen der stad Haarlem (The Hague, 1911) (Werken der Vereeniging tot uitgaaf der bronnen van het Oud-Vaderlandsche Recht, 2e reeks, XIII). 
very big step indeed, but, if we may believe his own words, the subject intrigued him. In the context of this investigation, Huizinga could not avoid pronouncing a judgment on the authenticity of Haarlem's town charter, but in arriving at a conclusion Huizinga had merely his intuition and common sense to guide him. In retrospect we may say that his reasoning was perfectly sound. Yet the 'real', that is, the trained mediaevalists used other instruments for this type of investigation: a thorough knowledge of diplomatics, of sigillography and of other auxiliary sciences, in which Huizinga had never been trained and which he had never taken up. Huizinga concluded that Haarlem's town charter was genuine. In 1923 he had the courage, or naiveté, to defend his opinion in a lively but nonetheless dignified article against the contentions of a pupil of Oppermann who in his doctoral thesis of 1921 attempted to prove that in the light of thorough diplomatic research the charter could not be regarded as genuine. Oppermann then took up the defence of his pupil. He did not refrain from drawing attention in a somewhat disparaging manner to what he saw as the amateurism of Huizinga's method. In his opinion Huizinga was not a mediaevalist but an old-fashioned dilettante. ${ }^{17}$ Since in these years almost all mediaevalists belonged to the Utrecht school, Huizinga's place was clear: outside the circle of his professional colleagues. Insiders will not be unacquainted with the fact that the young doctor whose views were attacked by Huizinga, Dr. C. D. J. Brandt, later came to oppose the excessive scepticism of Oppermann's school with regard to the authenticity of mediaeval charters and no longer supported the conclusions of his own dissertation. It is equally well known that, much later, the dissertation of H. P. H. Camps removed practically all doubts (apparently for good) as to the authenticity of the Haarlem charter. ${ }^{18}$ This, of course, does not vindicate Huizinga's somewhat questionable methods of investigation - it merely indicates the accuracy of his intuition.

This was the climate of opinion in 1919 when Huizinga published his Herfsttij. Herfsttij was based on chronicles, not on charters, it was a book not about politics, economic history or institutions, but about - as was stated in the subtitle - 'forms of life, thought and art'. The small circle of Huizinga's colleagues was shocked that a professor of history, including mediaeval history, could write a book so clearly opposed to the spirit of modern scholarship. But could one have expected anything different from a man whose inaugural lecture of 1905 had dealt with so elusive a subject as 'The aesthetic element in historical thought'? (VII, 3-23) ${ }^{19}$ In short, the

17. C. D. J. Brandt, Bijdrage tot de kritiek van Hollandsche stadsrechten der XIIIe eeuw (Utrecht, 1921); J. Huizinga, 'Noodwendig vertoog' (II, 22-34); O. Oppermann, Opmerkingen over Hollandsche stadsrechten der XIIIe eeuw (Utrecht, 1923) 18-26.

18. H. P. H. Camps, De stadsrechten van graaf Willem II van Holland en hun verhouding tot het recht van 's Hertogenbosch (Utrecht, 1948).

19. English translation in: J. Huizinga, Dutch civilisation in the 17th century, and other essays (London, 1968) 219-243. 
reactions published were not enthusiastic. The work was seen as rather unscholarly and not up-to-date, in fact as old-fashioned.

In the Netherlands another interesting objection was raised. In a long article, published in the general magazine Onze Eeuw ('Our Century'), ${ }^{20}$ the Utrecht archivist Muller praised Huizinga's achievement but rejected his results, on the grounds that the sources he used were one-sided and were responsible for the fact that the political and economic aspects of the period had been passed over. He also issued a stern warning to Huizinga: the practice of scientific inquiry, he wrote, and the attempt to give a literary form to the outcome of such an inquiry are two things which it is dangerous to combine. To quote him: 'Literary laurels are always somewhat dangerous for an historian.' Thus Huizinga's book was a failure as a scholarly historical work and it was literary in form. Was it then indeed - as evil tongues would have it - no more and no less than a novel?

It will have become evident by now that Franz Arens was right in thinking that Dutch historians were not sympathetic to Herfsttij and that in the Netherlands it might be necessary to break a lance for the value of narrative sources. Naturally Huizinga did not publicly respond to the many reviews of his work, certainly not to the reviews of the various translations. But in a letter to his publisher, H. D. Tjeenk Willink in Haarlem, dated January 10, 1920, Huizinga made a short comment on Muller's article in Onze Eeuw: 'Yesterday I read Muller's article. It was really rather silly'. This is not the reaction of a deeply shocked man. What Huizinga probably thought was so silly about Muller's views and those of all the other Dutch historians as well, was that they simply overlooked the fact that the subtitle of the book had set very definite limits to the subject. In his preface to the second Dutch edition Huizinga emphatically drew attention to this subtitle, since it also explained the one-sidedness of his source material.

More than ten years later, Ter Braak and Van Eyck put forward the hypothesis that, indirectly, the rather indifferent or hostile tone of the Dutch reviews exercised a major influence on Huizinga's development. They surmised that Huizinga was deeply shocked by the fact that Herfsttij was so coolly received by Dutch historians and so loudly praised by literary critics. According to Van Eyck this had two consequences. After this time Huizinga increasingly emphasized the cultural value of critical, scholarly historiography. Secondly, Van Eyck says, Huizinga started to attack pseudo-history with ever-increasing bitterness. All this meant that 'the sifter of facts' had overcome 'the creator of forms'. I am personally very sceptical about this interpretation which I do not think corresponds to the facts, and I can find no indication whatever that Huizinga ever, then or later, saw his Herfsttij as a work that it would be fair to compare in any respect with the pseudo-history or 'histoire parfumée' he despised.

20. S. Muller Fzn., Onze Eeuw, I (1920) 78-104. 
If the Dutch historians totally failed to understand the greatness of Herfsttij, did the historical profession outside the Netherlands immediately perceive its real value? Not at all. The Belgian historians, for instance, paid very little attention to Huizinga; the Revue Belge de Philologie et d'Histoire mentioned the second Dutch edition only in the list of new books and in a later volume also the Spanish translation was merely catalogued. In the Revue $d u$ Nord (partly Belgian), which was founded in 1940, Huizinga's name was never mentioned, neither through any discussion of his books nor through an obituary. When I studied at the University of Ghent during the academie year 1947-8, I noticed that the students had no knowledge of Huizinga and had not read any of his works. They explained this by saying that their professors did not consider the reading of his works at all necessary. I do not know if this was true, but certainly the more advanced students with whom I had contact found it very strange that I had spent a good deal of time preparing the bibliography of Huizinga printed in the last volume of the Verzamelde Werken and correcting the proofs of several other volumes.

In England two reviews of Herfsttij were published in 1925. They probably did not stimulate English interest in the book. The English Historical Review published a review of two and a half pages by Kingsford, ${ }^{21}$ which is so confused and incoherent that the reader of today is unable to make out what the author was trying to say. Kingsford started by suggesting that a work like Herfsttij could not have been written about the English fourteenth and fifteenth centuries, since neither the fine arts nor the literature of the period could be compared with their Burgundian counterparts. I must say I have my doubts about this, but I do not pretend to know better. Then he contends that a human being of the fifteenth century probably felt the same passions as we do today. Huizinga would have discovered this, he says, if he had seen more private letters and archive material. Our immediate question here is: where would one be able to find such private correspondence? But although Kingsford does not seem to have grasped the full significance of his own remark, it must be emphasized that he drew the attention to a vital problem which - as I shall indicate later - it was the merit of Lucien Febvre to explore further. Finally a direct quotation from Kingsford's review:

Dr Huizinga, in his protest against the methods of the scientific historian, who is in risk of neglecting the difference of tone in the life of the fifteenth century and makes a craze of economie causes, has somewhat obscured the political and social evolution which was the real moving force of the times.

Huizinga, according to this reviewer, did not see 'the real moving force'; this, of course, was a fatal flaw. But was it really true that Huizinga had placed himself explicitly in opposition to the scientific historian? What kind of historian did Hui- 
zinga consider himself to be then? Kingsford probably did not contribute to Huizinga's fame in England.

More sensational, and therefore undoubtedly more stimulating for the sale of the book, must have been Crump's conclusion in History in the same year 1925: ${ }^{22}$

And yet it leaves on the mind a curious impression, a sort of suspicion seizes the reader that if Professor Huizinga is right, most men who lived in the fourteenth and fifteenth centuries must have been practically insane.

In a sense he is right, A psychiatrist told me, when I asked him about it, that, if the Herfsttij-people were walking around in Europe today, they would very quickly be shut up in a mental institution. Insanity, however, is a time-and-culture-bound concept, and certainly on this point we should not apply modern standards to persons living in the fifteenth century. Here again, the reviewer raises an essential point, but, as it were, without realizing it. And again, it was Lucien Febvre who later recognized the real significance of the problem, that is the problem of historical psychology.

One gets the impression that the American historical journals were much more sympathetic towards Herfsttij. Doubtless this was a consequence of their own brand of mediaeval scholarship which allowed for the use of chronicles rather than of archive material, which was not easily available. Nevertheless an anonymous reviewer $^{23}$ describes the book as somewhat extravagant and therefore ultimately unsatisfactory. In the American Historical Review, however, appeared a fairly enthusiastic review. Although the conclusion of Herfsttij is considered disappointing because 'the advent of the new form' was not sufficiently developed, there is on the other hand so much praise that the review as a whole may be characterized as laudatory. It is interesting that the reviewer notices that Huizinga made use of psychological and sociological 'laws'. About the first two chapters he says: 'This seems altogether too sweeping and sociological'. In 1925, apparently, this was not good form, at least not in the $A H R .^{24}$

Let us now turn to the German reviews, which - whether or not they ultimately influenced Dutch opinion - are distinctly positive, although here too there is no lack of criticism. The essential difference between the reviews we have discussed earlier and these German reviews is that the German historians and art historians were perfectly aware that they were criticizing a fundamentally important book. This is not apparent in the Dutch, Belgian, British or American reviews.

Some art historians refused to accept unquestioningly Huizinga's thesis that the painting of the brothers Van Eyck did not herald any kind of Renaissance. Richard

22. C. G. Crump, History, X (1925) 163-164.

23. The Nation, CXXII (1926) 262.

24. G. C. Sellery, American Historical Review, XXXI (1925-1926) 113-114. 


\section{F. W. N. HUGENHOLTZ}

Hamann, ${ }^{25}$ for instance, compared Herfsttij to Burckhardt's Cultur der Renaissance, and attempted to prove, chapter for chapter, that the new form that was coming was far more important than Huizinga suggested. His criticism sounds somewhat strained. But Huizinga had, of course, been conscious of the fact that art historians in particular would contest his position on this subject. His intuitive conviction that the Van Eycks did not belong to the Renaissance was one of the main premises of his description of the late Middle Ages.

The Historische Zeitschrift ${ }^{26}$ described Herfsttij as an important book and stated - unlike the Dutch reviewers - that the work combined strict scientific investigation with a very readable style. It is worth noticing that the $H Z$ reviewed Herfsttij before the German translation was published. The Archiv für Sozialwissenschaft und Sozialpolitik, however, is disappointing because in the review on Herfsttij which it printed, no socio-political, socio-historical or even sociological comment is to be found. ${ }^{27}$ The reviewer rejected, as the art historians also did, Huizinga's judgment on Jan van Eyck. In the Archiv für Politik und Geschichte Franz Arens ${ }^{28}$ praised Herfsttij exuberantly, but raised a fundamental question. If one agrees, he wrote, with Huizinga's dictum that dreams are more important than census and tax figures, must one then necessarily conclude that reality outside such dreams consists exclusively of these figures? Were not the dreams of the Herfsttij people an anachronism, and did not a very important primary reality exist beside those dreams, a reality certainly not made up of facts and figures alone?

Finally, in the Göttingische gelehrte Anzeigen ${ }^{29}$ appeared a seven-page review of Herfsttij by A. Hessel. There, at last, it is approvingly stated that thanks to its psychological analysis of late mediaeval men, the book is modern. This is a remark with which I heartily agree. If an uninitiated reader happens to look at this paper he may well come to the conclusion that I am dealing with an old-fashioned book, and indeed this was exactly what in some circles it was considered to be. I was delighted when at last I found a review in which a professional historian emphasized its modernity.

But Hessel had some critical remarks to make as well, one of them being that in his view Herfsttij was too vague a book. He hardly elaborated this, but I have the impression that he intended to express the feeling formulated with rare precision by Huizinga's son Leonhard:

Even in that masterwork, Herfsttij, I sense that curious inability to bring the whole to a good conclusion, which for me typifies some of his works. At the beginning I have

25. Richard Hamann, Repertorium der Kunstwissenschaft, XLVI (1925) 151-152.

26. See note 9 .

27. Hans Huth, Archiv für Sozialwissenschaft und Sozialpolitik, LIV (1925) 252-254.

28. See note 11 .

29. A. Hessel, Göttingische gelehrte Anzeigen, CLXXXVI (1924) 81-87. 
the feeling: Here is a perfect work of art being created. Here he is building a bridge which, in one mighty span, in superb harmony and symmetry, will reach the other side. But, later, doubts arise. Does not the almost completed bridge stop short in the scaffolding when its builder loses himself in ever new examples of his thesis, and thus in repetition? $?^{30}$

I know of no other evaluation that combines so much basic criticism with so much justified sympathy.

The last German reviewer I mention here is Hans Günter, who in 1926 wrote a very extensive article in the Historisches Jahrbuch der Görresgesellschaft. ${ }^{31}$ Günter probed deeply into the psychological aspect of Herfsttij and he expressed serious criticism:

Problems are described for which the explanation that such behaviour is universally human is adequate. The tension which the book discusses in chapters one and thirteen is not mediaeval but universally human, and indeed modern too, as long as good and evil, passion and conscience exist side by side and opposite each other.

This brings us to the interesting question of how modern French historiography, whose greatest contribution I consider to be the discovery of the 'histoire des mentalités' or psychological history, reacted to Herfsttij. The French history of Herfsttij contains an element of tragedy. Very soon after 1919 Gabriel Hanotaux was already trying, through the Dutch and French Academies, to have the work published in France. It was translated at once, but Hanotaux could not find a publisher. It was only in 1932 that Herfsttij at last appeared in French, with a preface by Hanotaux himself. ${ }^{32}$ This preface may be partly responsible for the fact noted by Lucien Febvre, ${ }^{33}$ that the book was so little known in France. It may not have been too stimulating to read in the preface: 'The state is order; law is its measure; work is salvation; and finally: let us gather from this book many an edifying lesson'. Perhaps it is not fair to be so sceptical now about statements made thirty years ago, but Hanotaux was already 79 years old in 1932 and although he was an honoured member of the Academy, it is doubtful if he was still very influential. And surely, he was not the right propagandist for Herfsttij.

Although the French are sometimes criticized with some justification for ignoring foreign publications, I know at least five French reviews of Herfsttij written even before the French translation was published. Four reviewers discussed the first German edition, one, Marc Bloch, the second. One of these early reviews is more comical than important, for us at any rate. The Revue Bénédictine was irritated by the fact that Huizinga showed little appreciation for the simple beliefs of the Catho-

30. Leonhard Huizinga, Herinneringen aan mijn vader (TheHague, 1963) 194.

31. H. Günter, Historisches Jahrbuch der Görresgesellschaft, XLVI (1926) 622-630.

32. J. Huizinga, Le Déclin du Moyen Age (Paris, 1932).

33. Lucien Febvre, 'Comment reconstituer la vie affective d'autrefois. La sensibilité et 1'histoire' (1941), Combats pour l'histoire (2nd ed., Paris, 1965) 226. 
lic faithful: 'Is there not a tendency toward a Protestant or Jansenist spirit discernible in his criticism of certain kinds of worship of the Virgin Mother and the Saints ? $^{34}$ Marc Bloch's review ${ }^{35}$ was the first of real importance in France. He described Herfsttij as 'a capital book', and as 'one of the most original and suggestive historical works that have been written for a long time.' One recognizes the founder of the Annales when he writes: 'It is a study of historical psychology, which is collective psychology, of course.' But in the Annales itself the first French edition of Herfsttij was not reviewed and this makes it somewhat difficult to ascertain what in those early years of its existence the members of this group thought about Huizinga's book. According to the testimony of younger members of the Annales Huizinga's work undoubtedly exercised a certain amount of influence in the sense that it was considered to be stimulating and in line with the preoccupations of the group. In a personal letter Robert Mandrou kindly told me that Lucien Febvre always spoke of Huizinga with the utmost respect and admiration, an attitude also apparent in his preface to the French translation of Huizinga's Erasmus. In other passages Febvre wrote about Huizinga in the same way. In 1935 he described Herfsttij as an admirable psychological monograph, ${ }^{36}$ in 1938 as 'a highly suggestive book' in which, however, - and this was a fundamental critical note - much was stated without being explained; explanation, he thought, called for more systematic research. ${ }^{37}$ In 1941 Febvre wrote ${ }^{38}$ that in France the book had not had the success it deserved. Trying to account for this he sought for other than merely external factors and asked himself whether weaknesses in Huizinga's own conception might have been one of the causes of French indifference. Indeed, did the late Middle Ages constitute 'a special and distinct period in the affective history of man?' According to Lucien Febvre, Huizinga's starting point was questionable. He should first have realized that humanity generally is characterized by an 'ambivalence des sentiments', and thereafter he should have asked himself if in some periods particular elements in the spectrum of human sensibility are more prominent than in others. Only then would he have been able to approach the subject from the right angle.

Although both Mare Bloch and Lucien Febvre continued throughout their life to give Herfsttij the full measure of their admiration, in the course of the years they came nevertheless to formulate increasingly critical reservations. Small wonder! In the beginning they were delighted to discover a kindred spirit, but the more refined their own research methods in the 'histoire des mentalités' became, the more sharply aware they themselves became of Huizinga's shortcomings in this

34. P. Rox, Revue Bénédictine, XXXVIII (1926) 87-88.

35. See note 10.

36. Lucien Febvre, 'De Sluter à Sambin', Combats, 300.

37. Lucien Febvre, 'Une vue d'ensemble. Histoire et psychologie', Combats, 215.

38. See note 33 . 
respect. It is a great pity that Herfsttij was published so late in the only country in which, through its approach and its method, it could have exerted influence in 1919 and in the years immediately thereafter. When it finally was published, it was regarded as a work related in spirit to the Annales but lacking the precision of method which the Annales-group was trying to establish.

Let me summarize. In surveying the whole corpus of reviews of Herfsttij the reader cannot help being surprised by the fact that only very few authors were able to understand what was so unusual about a book which some of them greatly admired. Comment upon Huizinga's use of source material remained superficial. The reviewers failed to recognize that Huizinga was exploring what was to become a totally new field of historical research, the 'histoire des mentalités' or psychological history. Only the French at that moment would have been able to see it. All reviewers, with one exception, missed another important point which to us is obvious: the connection between Herfsttij and Burckhardt's work. One has the impression that in his studies on the Renaissance Huizinga himself was the first to draw attention to this. It is equally striking that none of the reviewers made any comment on Huizinga's aristocratie attitude or his cultural pessimism. When many years later Herfsttij was often mentioned in discussion of Huizinga's conception of cultural decline, this was due to his In the Shadow of Tomorrow. Before the publication of that book no one had ever done so.

This, then, was Herfsttij in the years when Huizinga was not yet a European figure; this was Herfsttij without the later Huizinga: an unusual book that, notwithstanding its sales figures, became influential much more slowly than one might have supposed, a book that was not old-fashioned in 1919 but, on the contrary, in several important ways too modern to be immediately understood.

Probably the author, working and studying all by himself in a somewhat isolated situation, did not anticipate the influence of his approach and method. As far as I know he did not notice that in the 1930s Marc Bloch and Lucien Febvre, both of whom he admired, were starting a school and a periodical in which some of his own preoccupations were more fully and systematically developed. Huizinga had little interest in methodology. Yet he wrote a book that gives much more than a brilliant portrait of a period. It inspired historians to look at history generally in a totally new manner. 